\title{
Gravity Modeling of Recreational Tourism (In the Example of Namangan Region of the Republic of Uzbekistan)
}

\author{
Zuhrali Abdulkhakimov Tursunalievich, Madina Ibragimova Ismailovna
}

\begin{abstract}
As a result of specialization and integration of tourist and recreational activities in recreational health improving zones, recreational tourism started developing rapidly in the regions. Gravity models are widely used in the study of development of therapeutic and recreational industry. The problem concentrated in this article is developing the theoretical, methodological and practical recommendations for improving the "gravity rings" of recreational places by using gravity models in the example of Uzbekistan regions. For investigation the problem there were applied statistical data gained from gravity models of recreational development in the equation models. Based on theories of gravity modelling, the results of the development, study and implementation of recreation in the regions increase accuracy, the reliability of decisions and take into account the predicted results. The feasibility, accuracy and reliability of the approaches and methods used in the study are based on econometric and mathematical methods, and statistical data is based on the analysis of the data provided by the State Statistical Committee of the Republic of Uzbekistan and the survey data of recreational facilities in the selected region.
\end{abstract}

Keywords: therapeutic and recreational industry, tourism, gravity models

\section{INTRODUCTION}

In the long term strategy of economic development of the Republic of Uzbekistan, many Presidential Decrees are aimed at accelerating the development of the country's regions and their regional improvement strategies taking into account the characteristics of each region. Structural changes and the accelerated development of modern high-tech industries and policies in the field of tourism and leisure are considered as a key priority for the Republic of Uzbekistan in increasing its competitiveness and position in the world market. The development of tourism and recreational

Revised Manuscript Received on December 30, 2019.

* Correspondence Author

Zuhrali Abdulkhakimov Tursunalievich, Department of Organization and Economics of Industial Production, Namangan Institute of Engineering and Technology, Namangan city, Uzbekistan, zuhriddin-75@mail.ru, (+99894)1710025

Madina Ibragimova Ismailovna, Department of Economic theory, Samarkand Institute of Economics and Service, Samarkand, Uzbekistan, m.ibragimovuzb@gmail.com, (+99897)7772677

(C) The Authors. Published by Blue Eyes Intelligence Engineering and Sciences Publication (BEIESP). This is an open access article under the CC BY-NC-ND license (http://creativecommons.org/licenses/by-nc-nd/4.0/) activities in the regions will open unused opportunities and increase additional revenues to the local budget. Tourism and recreation are the most profitable and effective income sources for countries with economies in transition. They

provide opportunities for the development of other sectors through tourism and recreation in the regions and play as a locomotive for the development of the regional economy. Therefore research in this area is considered to be a relevant issue to solve. Correct approaches need to be used in applying to the gravity models for the development of tourism and recreation in the regions. It is necessary to carry out in-depth study of the processes of their implication in solving tourism and leisure issues, and analysis of the factors influencing to the industry with econometric and mathematical methods as well as analytic results gained from gravity models, furthermore it is vital to create a virtual platform for advertising, attracting tourists to the touristic and recreational places.

\section{LITERATURE REVIEW}

Integrated, integral and systematic approach has to be applied in order to study the complexity of tourist and recreational activities. The main approach in the investigations should include several models of organizing and improving the touristic recreational industry in the regions. The regional development models were designed by J.H. von Thunen (1826), W.Laundhardt (1882), A.Weber (1909), W. Christaller, A.Lyosch (1940). The main attention in these models is paid to tourist and recreational migration [12]. Riley's Gravity Model (Riley's/Converse's Model) - in large cities, there are large consumers who prefer to attract them from local sales representatives, since they are far from large trading points for the delivery of finished products. This gravity model has been used in commerce. "This model was developed in 1931 by Professor W.D. Riley at the University of Texas in accordance with Newton's universal law of gravitation. Then in it was completed by P.D.Converse. In 1931, Riley published his book "The law of retail gravitation". [10] "Riley was one of the first to analyze the retail competitiveness of the retailer and developed a law of retail gravitation" [6]. This law consists of the following requirements: the space is the same: there are no rivers, roads or mountains; change of consumer requirements, where to go, what goods to buy based on consumer choice in cities; it promotes competition between trade points. 


\section{Gravity Modeling of Recreational Tourism (In the Example of Namangan Region of the Republic of Uzbekistan)}

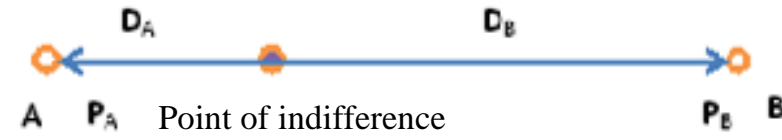

Fig.1 Riley diagram

As can be seen from the diagram above, consumers $\mathrm{C}$ are located between trading points A and B. Trading points, in turn, create trading areas [15]. The attraction of consumers depends on the size of both trading points. $P_{A}$ and $P_{B}$ are trading areas. The number of customers participating in both trading points depends on their activities, the number of consumers and the cost of the products. The study of migration processes in cities using the Riley gravity model allows one to explore urban migration processes and identify levels of inter-city economic relations [6]. Riley's gravity model is limited; it does not determine the domestic demand in the city and does not set the prices. The model is used for the analysis of trade turnover at the initial stage, in the passenger transportation, in the determination of goods and services delivery zones. Gravitational models are used to predict the socio-economic development of cities. American sociologist F. Cherry studied the influence of gravity on the processes of society in the middle of the $19^{\text {th }}$ century. D. Steward also worked with gravity model theories. The essence of his idea is that when people move in interdependence, they obey the laws and explore the demographic potential through demographic forces. D. Steward compiled a demographic potential card of the United States.

In tourism and recreational models, the main focus is given to the size and type of guest flow. The Clawson model works to increase the probability of visiting to a resort on the basis of the available empirical data. In this graph, distance is calculated based on the factors such as the distance and attractiveness of the space, as well as the satisfaction of travel. In this way, the recreational reception capacity of the recreational site, its distance and proximity of the population affects the volume of the recreational flow. This limits the scope of the recreational area. According to half-destination travel model by T.Gier and J.Hollen, where geometric cones are divided into three groups: the first is the one day trip zone, the second is the resort trip and the third is base holiday trips. Psychological inertia of people has been studied in R. Wolf's gravitational model. It has divided two types of human psychological inertia. First, the "Pacific Inertia" is a group of people who do not want to travel, and they want to travel a little distance. Second, "Animated inertia" is a group of people with long-term travel, and no distance for travel. P. Wilkinson's gravitational model was originally designed for smaller distances, where distance and human inertia were seen as a major factor. Thompson in his model investigated the interaction between recreational objects. K.Gering, U. Sugar, T. The gravity model of carbohydrates has been studied to evaluate international attractions.

Gravity models have been widely used to promote recreational and recreational activities in the regions, based on the above studies. The author proposed a scientific study of "Gravitational Rings", consisting of seven rings using the gammain to recreate activity and to use gravity models. The concept of rings in the development of "gravitation rings"

was derived from the "Tyne Ring" developed by I.G Tyunen . "In the vicinity of the Tynhen ridges, it creates its own circles around the city in the placement of agriculture. For example, the first of these rings consists of a highly productive urban environment, followed by the forestry sector, and the third one is fruits and seeds. Total Tyunen has identified 6 people " [13]. Also, in describing the "Gravity Rings" in recreational activity in Namangan region, the author proposed that B.N.Navruzzoda, N. Ibrohimov, Z.B.Navruzzoda, Sh.B.Navruzzada (2017) improved competitiveness was based on the conceptual model of "7M" [8]. On the basis of studying mono, mini, micro, meta, mezo, macro, megadarages gravitational rings in recreational activity were formed.

1. Mono gravitational rings - the shell of individual persons engaged in recreational activity;

2. Gravity rings - Housings of recreational activities;

3. Micro gravity rings - Recreational enterprises, organizations, shells;

4. Meta gravitation rings - a network of recreational networks and spheres;

5. Meso-gravity rings - Recreational areas and the territory-scale farms;

6. Macro gravitation rings - country-class crustaceans;

7. Mega gravitational rings are understood as crusts of international level of recreation.

\section{Hypothesis}

Recreation - today quality and quantity is evolving. Austria, Canada, France, Spain, Sweden, the United Kingdom, the United States are among the most developed countries of tourism and recreation. "The tourism economy has become an active phase of development over the next 50 years" [5]. "It has a place in the economy of cities and regions of the world. They are in the process of long-term internationalization and integration".[7] Treatment and rehabilitation is one of the most important types of recreational activities. It focuses on human health, the process of reducing the lost work ability of people as a result of labor activity. This is one of the most urgent tasks of the day. The treatment-and-recreational recreation has a very ancient history. In the 20th century the whole resort industry was formed. In the structure of this industry new health forms have been formed on the basis of traditional climatic, balneological and therapeutic resorts - spa, wellness, fitness. Modern sanatorium-resort organizations are provided with services of check-ups. Development of recreation and recreation centers is an effective way of development. Health promotion is the treatment of psychological, physical and mental stress through a natural environment during human labor activities. In the natural environment, people are resting on the central nervous system. The time, place, and duration of the holiday have a positive impact on the recovery process of the human body. The organization of meaningful leisure time in the leisure of a person. 
During this period, they will have to continue the treatment and rehabilitation with the loss of failures and completely forgetting their performance. At the same time, it is required to develop the ways in which the regions of the Republic of Uzbekistan can fully utilize their capacities and capabilities and to study their capacities. Recreational activities are the most important type of recreational and recreational recreation. "It is a complex process to study the treatment and rehabilitation. It needs a systematic approach. A high-definition research strategy is required. Sanatorium-resort system is a complicated system that uses a wide range of natural resources and is influenced by many factors (natural resources such as mineral water, clay, climate, social shell - recreational, service and management personnel, environmental impacts). [9]

This type of recreation includes sanatoriums, sanatoriums, health resorts, holiday homes, boarding houses and leisure bases. The recreational and recreational forms of recreational activities include sanatoriums, sanatoriums and health resorts, as well as resort clinics. In the outpatient clinics, water, mud treatment and excellent medical care are provided. "Other trends in activity are seasonal signs, and in sanatoriums in these regions, there is high pressure in sanatoriums when customer traffic occurs" [11].

"Differentiation levels of concentration and supply of territorial units have been identified as a result of the integration of the services of the sanatorial and resort organizations in the regions of Uzbekistan to the following groups. Most developed regions include Tashkent, Ferghana, Namangan, and Tashkent."[14] Sanatoriums are referred to an organization that has a material base in a given area. They mostly work on the basis of natural healing properties. Natural sources of treatment are made up of climatic resources, where they are treated with bioaccumulation, balneology, mineral waters, therapeutic mud and health improvement. Sanatorium treatment cycle lasts for 21 to 24 days. These treatment cycles can be added to the customer's wishes and to the opinion of experts. In the sanatoriums for treatment of natural sources of treatment based on biological factors. Balneological sanatoriums have mineral water and mud therapy. In climatic balneal sanatoriums, complex treatment of all natural treatments has been started (fig.2).

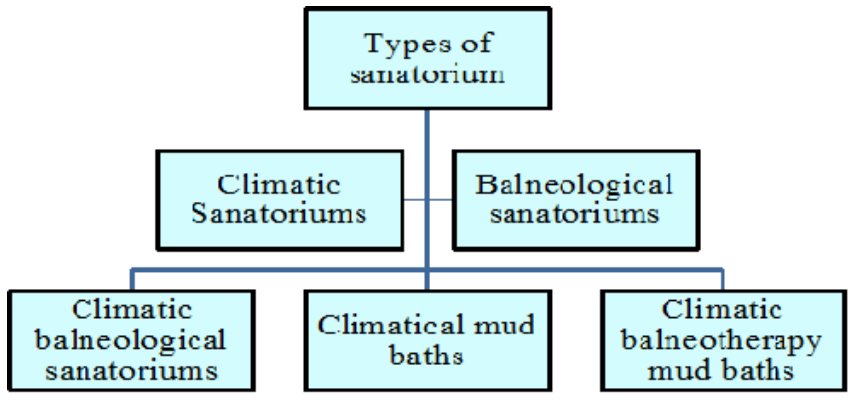

Fig. 2 Types of sanatorium ${ }^{1}$

Various kinds of diseases are divided into tuberculosis diseases, diseases of the nervous system, cardiac diseases, respiratory diseases, and sanatorium for the treatment of stomachaches. Resort sanatoriums are divided into three basic functional zones. They include departments of treatment, department of management, service personnel. The largest area is the treatment unit. They include treatment rooms, dormitories, winter and summer sports complexes, kitchens, climatic treatments, sanatorium parks. There are hotels in the dormitory. The kitchen system includes restaurant service and diet preparation for rest. There are also phyto and nonalcoholic bars. The treatment unit consists of several departments: diagnostic center, physiotherapy, hot and light therapy center, psychotherapy, therapeutic exercise, mechanotherapy, hydropathy, massage rooms (needle therapy, galotherapy, dentistry) and water treatment baths swimming pools. There are many health clinics around the sanatoriums. In the sanatoriums there are libraries, cinemas, dance halls, various games, treatments and climate pavilions.

The economic division consists of the economic units of the sanatorium. It includes garages, heating systems, workshops and warehouses. The serving staff includes recreational activities, various medical specialists, nurses, dietetic staff, recreation personnel, mineral water producers, accounting staff, sanatorium transport drivers. Organizations engaged in sanatorium-and-sanitary- improving activities include organizations engaged in health-improving activities in the early morning and evening hours. Therapeutic pension funds operate in cooperation with organizations and sanatoriums having several smaller therapeutic bases. If these hostels are located in large resort zones, these institutions are called resort health clinics. "Holiday homes have appeared in the 20th century. They also operate as a boarding house, have limited rest time, sports equipment, sauna and swimming pools. Hostels began to develop in the 18th century. These organizations were established to improve the health of the population. Initially, adults were resting, and later they enjoyed their families, children, and health improvement They have 12 or 24 days of rest. But in these resorts there are no rest periods. Holidays are taken into account. Recreation centers are a holiday destination in these organizations. This holiday is made during summer vacation.

They are administered from one to 12 days. Vacation time limits are not limited. These are small bases that do not have heating systems. But little conveniences for the summer season have been created. " [3] Sanatoriums, holiday homes and boarding houses are also trying to develop material and technical bases. There are also bedrooms, kitchens, cinema, concert halls, dance halls, libraries, sports complexes, several treatment rooms (massage, stomatology). Many holiday homes and boarding houses are equipped with swimming pools, saunas, tennis courts, and sports equipment.

In the system of economic and mathematical modeling of recreational and recreational processes, demand models for the use of recreational activities play an important role. This, in turn, increases the efficiency of the use of the regimen.

There are many scientific approaches, directions, and models for identifying and studying recreation requirements. The research has been widely used in today's world-renowned tourism and recreational systems, based on gravitational models that are commonly used to forecast recruiting, and have been applied to the process based on regional characteristics. 


\section{Gravity Modeling of Recreational Tourism (In the Example of Namangan Region of the Republic of Uzbekistan)}

The origin of the name "gravitational model" is based on the assumption that the whole world gravitates to the recreational areas and the disparity between the nibaten population and the development of mutual relations between them. Gravity model (gravity in Latin means weight, strength, movement). This model is a process of gravity taking into account the distances between interconnected and interconnected objects (cities, regions, countries) in social or economic terms. This model also has a regional character, under which its urbanization, placement of production forces, export-import relations, and population migration processes.

\section{METHODS}

One of the health-improving objects of recreation in Namangan region, Chartak sanatorium has been studied by gravity models. Gravity rings have been created to explore the possibilities and problems of recreational facilities in the region. According to the study, primarily based on gravitational rings, it is possible to refer to the classical model of the model class for groups of distance between 100-150 $\mathrm{km}$ and more distant, depending on the distance of current visitors in recreational systems.

$$
K_{\mathrm{i} j}=k \frac{\mathrm{m}_{i}^{\mathrm{x}_{\mathrm{n}}{ }_{j}^{y}}}{v_{\mathrm{ij}}^{7}}
$$

Here: $K_{\mathrm{ij}}$ - $j$ number of recreational tourists visiting tourist and recreational systems on demand in the local popu- lation.

$n_{j}-j$ - the maximum number of tourist and recreation systems;

$\beta$ - the rate of change in the volume of recreation systems;

$\mathrm{m}_{i}$ - $i$ - population demand;

$\propto$ - attractiveness coefficient of recreation systems;

$\mathrm{r}_{\mathrm{ij}}$ - $i$ - with a settlement $j$ - distance between tourist and recreation systems;

$y$ - Convenience coefficient (road, migration and road fare).

$\propto, \beta s \gamma$ - coefficients were calculated using the amount determined on the basis of the survey.

It is desirable to consider the Chortoq sanatorium for the treatment of therapeutic activity in the Namangan region of the Republic of Uzbekistan. Because of this, within the framework of the Namangan region, the opportunity to fully exploit the situation of mountain and therapeutic health promotion. Therefore, according to the methodology described above (1), the calculation will be based on the distance between the area of visitor residence and the distance to the location of the "Chartak" sanatorium and the population of that region (Table-I).

Table-I: Information about areas $100-150 \mathrm{~km}$ from the Chartak sanatorium ${ }^{2}$

\begin{tabular}{|l|l|l|l|}
\hline & $\begin{array}{l}\text { Namangan } \\
-87 \mathrm{~km},\end{array}$ & Fergana - & Andijan - \\
& population & $132 \mathrm{~km}$, & 82 km, \\
& -2699.0 & population & population \\
& thousand & -3620.1 & - 3011,6 \\
Fergana & people & thousand & thousand \\
valley & & people & people. \\
\hline
\end{tabular}

${ }^{2}$ Source: https://flagma.uz/ru/rasstoyanie-dzhizak- author's development based on the data received

\begin{tabular}{|l|l|}
\cline { 2 - 2 } $\begin{array}{l}\text { Neighboring } \\
\text { countries }\end{array}$ & $\begin{array}{l}\text { The Republic of Kyrgyzstan, the } \\
\text { Jalal-Abad Province. Ola-Bulga - } 75 \\
\text { km, population - 1201.7 thousand. }\end{array}$ \\
\hline
\end{tabular}

Based on the table data (1), the Chartak sanatorium uses the gravitational model to determine the power of attraction of each of the regions by attracting tourists. It features the features of the system that encourages the visitor to visit, including the attractiveness, accessibility and variation in the volume of recreation sites (Table -II).

Table-II: Capture of "Chartak" sanatorium from the regions by the population demand ${ }^{3}$

\begin{tabular}{|l|l|l|}
\hline & Regions & Gravity force \\
\hline 1 & $F_{\text {Namangan }}$ & 0,00118962 \\
\hline 2 & $F_{\text {Fergana }}$ & 0,000613602 \\
\hline 3 & $F_{\text {Andijan }}$ & 0,001071487 \\
\hline 4 & $F_{\text {Jalal-Abad Province }}$ & 0,000121225 \\
\hline
\end{tabular}

According to the table data, the closer the distance is, the higher the gravitational force. Chartak sanatorium is located in Chortoq district of Namangan region, where FNamangan = 0.0012 is equal to that of Jalal-Abad's sanatorium in Kyrgyzstan, which is relatively poor compared to other regions, including certain aspects, such as border posting and registration documents a series of tasks. The results of the research and the calculations are shown in the following table.

Table-III: The number of visitors to the Chartak sanatorium is $100-150 \mathrm{~km}^{4}$

\begin{tabular}{|l|c|c|c|}
\hline Regions & $\begin{array}{l}\text { Population } \\
\text { demand }\end{array}$ & $\begin{array}{l}\text { Intermediate } \\
\text { distance }\end{array}$ & $\begin{array}{l}\text { Number } \\
\text { of } \\
\text { visitors }\end{array}$ \\
\hline Namangan & 12146 & 87 & 3211 \\
\hline Fergana & 10860 & 132 & 2221 \\
\hline Andijan & 10541 & 82 & 3227 \\
\hline $\begin{array}{l}\text { Jalal-Abad } \\
\text { Province }\end{array}$ & 3966 & 75 & 146 \\
\hline
\end{tabular}

It should be noted that at today's 12,146 sanatoriums of Namangan region, only $26.4 \%$ (3211) of those who want to rest and get treatment, $20.5 \%$ of the total population of Fergana and Andijan regions, and 30.6\% it was found out that they visited the "Chartak" sanatorium for treatment. If you look at neighboring countries you can see 146 residents of the Jalal-Abad region of the Kyrgyz Republic. 
Table-IV: Information on areas over $150 \mathrm{~km}$ from the C.hartak sanatorium ${ }^{5}$

\begin{tabular}{|c|c|c|c|}
\hline $\begin{array}{l}\text { Across } \\
\text { the country }\end{array}$ & $\begin{array}{l}\text { Tashkent- } \\
330 \mathrm{~km}, \\
\text { population } \\
-5,326.9 \\
\text { thousand. }\end{array}$ & $\begin{array}{l}\text { Samarkand- } \\
\text { Syrdarya } \\
596 \mathrm{~km} \text {, } \\
\text { population- } \\
5860.2 \\
\text { thous. }\end{array}$ & $\begin{array}{l}\text { The Republic of } \\
\text { Karakalpakstan } \\
\text { - Navoi Region } \\
\text { - } 1383 \mathrm{~km}, \\
\text { population- } \\
\text { 6474.9 thousand }\end{array}$ \\
\hline $\begin{array}{l}\text { Teighborii } \\
\text { ountries }\end{array}$ & \multicolumn{3}{|c|}{$\begin{array}{l}\text { Tajkistan is } 297 \mathrm{~km} \text { from the Khujand region, } \\
\text { with a population of } 1,118,800 \text {. }\end{array}$} \\
\hline
\end{tabular}

Based on the model the distance and the population data, calculations are made. The calculation results are summarized in Table-V. Because the inertia in the method depends on the value a: $\mathrm{r}_{\mathrm{ij}}<a, \ln \left(\mathrm{r}_{\mathrm{ij}} / a\right)$ but the negative impact of distance on demand has increased, however, it should be noted that, given the proportionality of the model to population, the population of the Navoi region of the Republic of Karakalpakstan has increased the number of visitors from this region (Table-V).

Table-V: Information about those who visit more than $150 \mathrm{~km}$ from the C.hartak sanatorium ${ }^{6}$

\begin{tabular}{|l|l|l|l|}
\hline Regions & $\begin{array}{l}\text { At the } \\
\text { population' } \\
\text { s demand } \\
\text { (in number) }\end{array}$ & $\begin{array}{l}\text { Intermediate } \\
\text { distance, km }\end{array}$ & $\begin{array}{l}\text { Number } \\
\text { of } \\
\text { visitors } \\
\text { (persons) }\end{array}$ \\
\hline Tashkent & 15987 & 330 & 628 \\
\hline $\begin{array}{l}\text { Samarkand- } \\
\text { Syrdarya }\end{array}$ & 20511 & 596 & 552 \\
\hline $\begin{array}{l}\text { Republic } \\
\text { of } \\
\text { Karakalpakstan } \\
\text { - Navoi region }\end{array}$ & 155373 & 1300 & 1021 \\
\hline $\begin{array}{l}\text { Khujand } \\
\text { Province } \\
\text { of the Republic } \\
\text { of Tajikistan }\end{array}$ & 16812 & 305 & 138 \\
\hline $\begin{array}{l}\text { Regions } \\
\text { At the } \\
\text { population' } \\
\text { s demand } \\
\text { (in number) }\end{array}$ & $\begin{array}{l}\text { Intermediate } \\
\text { distance, km }\end{array}$ & $\begin{array}{l}\text { Number } \\
\text { of } \\
\text { visitors } \\
\text { (persons) }\end{array}$ \\
\hline $\begin{array}{l}\text { Tashkent } \\
15987\end{array}$ & 330 & 628 \\
\hline $\begin{array}{l}\text { Samarkand- } \\
\text { Syrdarya }\end{array}$ & 20511 & 596 & 552 \\
\hline $\begin{array}{l}\text { Republic } \\
\text { of } \\
\text { Karakalpakstan } \\
\text { - Navoi region }\end{array}$ & 155373 & 1300 & 1021 \\
\hline $\begin{array}{l}\text { Khujand } \\
\text { Province }\end{array}$ & 16812 & 305 & 138 \\
\hline
\end{tabular}

${ }^{5}$ Source: https://flagma.uz/ru/rasstoyanie-dzhizak- author's development based on the data received
According to the data of Table 5, 3\% (15987) of the total population of Tashkent and its districts are from the Samarkand region to Syrdarya region by $0.4 \%$ (20511) and $2.6 \%$ of the population of the Republic of Karakalpakstan and Navoi i (155373), of which 628, 552 and 1021, respectively, were rested in the Chartak sanatorium. However, it should be noted that the information about the attractiveness and competitiveness of the existing sanatorium and the expansion of the place of residence can increase the number of visitors.

It is important to note that the simplicity of the gravity models is their main feature. In this context, this model is often used for the study of socio-economic processes. Of course, the study of demand for the use of the recreational equipment is not limited to gravitational modeling.

Table-VI: Factor correlation coefficient ${ }^{7}$

\begin{tabular}{|llllll}
\hline & $Y$ & $X_{1}$ & $X_{2}$ & $X_{i}$ & $X_{4}$ \\
$Y$ & 1 & & & & \\
\hline$X_{1}$ & 0,982613438 & 1 & & & \\
$X_{2}$ & 0,989528976 & 0,672100549 & 1 & & \\
\hline$X_{2}$ & 0,977980546 & 0,794270607 & 0,776759449 & 1 & \\
$X_{4}$ & 0,9930600199 & 0,992672292 & 0,690457375 & 0,992375354 & 1 \\
\hline
\end{tabular}

Number of visitors to the "Chartak" sanatorium for recreation and treatment - use of available natural resources in the sanatorium, affecting its growth $-\mathrm{X}_{1}$, quality of services $-\mathrm{X}_{2}$, cost of a sanatorium $-\mathrm{X}_{3}$ and the state of the existing infrastructure $-X_{4}$ the regression equation of the factor. For this purpose, first of all, the correlation coefficient is determined by the interconnected factors and the factors influencing.

\section{RESULTS}

Chortoq sanatorium located in Namangan region of the Republic of Uzbekistan is one of the main health and recreational healthcare facilities in the region. Therefore, the object's attractiveness was studied by gravitation models. The seventh "Mega Gravity Ratio" operated by the gravitational model of the ettitic "Gravitational Rings" at the above-mentioned recreational facility seems to be faster. In order to develop these links, it is necessary to develop inter-regional and inter-state cooperative relations between recreational facilities and bases, clusters.

Using the above-mentioned method, recreational attractiveness and competitiveness of the object, prices for medical and recreational objects, proximity of objects to the object, processes related to psychological inertia of people were studied. Gravitation models can be determined by various methods, such as questionnaires, expertise, etc. The recruiting region selected for the study does not participate in international health resorts due to the lack of recruiting international recruits. Table-VI shows that the selected factors are strongly linked to the resultant factor, in the correlation between the competitiveness of Chartak

${ }^{7}$ Source: author's work on the basis of the data from the State Statistics Committee of the Republic of Uzbekistan 


\section{Gravity Modeling of Recreational Tourism (In the Example of Namangan Region of the Republic of Uzbekistan)}

sanatorium and the link between the infra-structure factor $\left(r_{x 3, \times 4}>0,8\right)$ Because of the multicolinguistic existence, the regression equation is constructed using the Eviews program and the model adequacy is checked between the factors that leave the infra-structure factor (Table-VII).

Table-VII: Measurements of the regression equation that reflects the increase in the number of visitors to the "Chartak" sanatorium for rest and treatment. ${ }^{8}$ Dependent Variable: Y

Method. Least Squares

Sample: 20062017

Induded observations: 12

\begin{tabular}{lllll}
\hline \hline Variable & Coefficient & Std Error & t-Statistic & Prob. \\
\hline \hline $\mathrm{X} 1$ & 9.821865 & 3.890847 & 2.524352 & 0.0356 \\
$\mathrm{X} 2$ & 11.85347 & 2.684991 & 4.414716 & 0.0022 \\
$\mathrm{X} 3$ & -5.935111 & 3.804693 & -1.559945 & 0.0514 \\
$\mathrm{C}$ & -96941.94 & 8998.508 & -10.77311 & 0.0000 \\
\hline \hline R-squared & 0.989993 & Mean dependent var & 9878.333 \\
Adjusted R-squared & 0.986240 & S.D. dependent var & 3385.195 \\
S.E. of regression & 397.0963 & Akaike info criterion & 15.06744 \\
Sum squared resid & 1261484. & Schwarz criterion & 15.22907 \\
Log likelihood & -86.40462 & Hannan-Quinn criter. & 15.00759 \\
F-statistic & 263.8026 & Durbin-Watson stat & 2.028768 \\
Prob(F-statistic) & 0.000000 & & \\
\hline
\end{tabular}

According to the data in the table, only one $t_{x 3}$ - option is insignificant ( $\mathrm{t}_{\text {account }}<\mathrm{t}$ table, $\mathrm{df}=11$ and $\propto=0,05$ when, $\mathrm{t}$ table $=2,2010$ ). Therefore, criteria for evaluating the quality of retrospective prognosis TIC $<1$ and MAPE $<10$ (fig. 3).

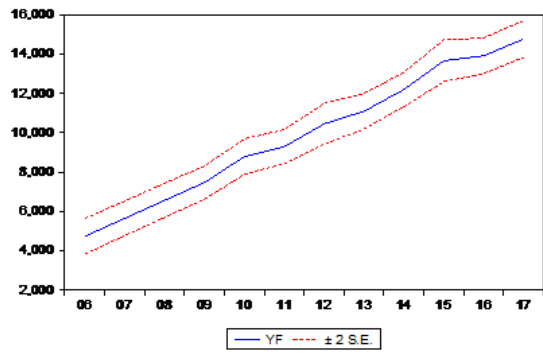

Forecast: Y

Actual: $Y$
Forecast sample: 20062017 Included observations: Mean Absolute Error Mean Abs. Percent Error Theil Inequality Coeffic
Bias Proportion ce Proportion

Fig.3 Retrospective forecasting quality ${ }^{9}$

Based on the information provided in Figure 3 $\operatorname{TIC}(0,02)<1$ and MAPE $(2,94)<10$ According to these predictive criteria, the prognosis is high and therefore the parameter is significant

$Y_{\text {sanatorium }}=-97790,79+9,8 * X_{1}+11,9 * X_{2}-5,9 * X_{3}$

the model is reliable and adequate.

Here: $Y_{\text {sanatorium - Number of visitors to sanatorium for rest }}$ and treatment;

$\mathrm{X} 1$ - use of existing natural resources in sanatorium;

$\mathrm{X} 2$ - quality of services;

$\mathrm{X}_{3}$ - cost of a sanatorium.

If this model is to be explained, then the use of existing natural resources in the sanatorium and the increase in the quality of services will result in an increase in the number of visitors to the sanatorium for an additional 9.8 and 11.9 units, respectively, and the cost of sanatorium it was determined that it should be reduced as much as possible.

Improving the competitiveness of the region's health and therapeutic recreation through the development of such high-profile sanatoria-resorts. Sanatoriums of the region are functioning effectively on the basis of local, regional, interregional and international competitiveness. Therapeutic-recreational recreation occurs on the basis of cooperative, vertical and horizontal. The sanatoriums in the region need to develop interconnected, in practice they are advancing dynamically because some sanatoriums are in the Ministry of Health, some are the federation of trade unions, and some are private sanatoriums. There is no strong relationship between them. Therefore, it is necessary to intensify cooperation in this area. They open up their new options.

\section{DISCUSSIONS AND CONCLUSIONS}

It should be emphasized that rapid development of recreational activities in the regions is one of the most important aspects of recreational facilities, their efficiency. It is important to use gravitational modeling to attract recreational objects to recreational facilities. These models are based on the characteristics of the regions and their recreational activities, recreational resources availability, recreational appeal of the region, and the entrepreneurship of the population. Expected revenues from reductions in regions can either increase or decrease significantly, largely depend on the potential for recreational resources, the level of development of recreational infrastructure, laws, decrees, and state-of-the-art practices in the country. These processes are largely influenced by human factors, their standard of living, and employment.

The application of gravity models in the application requires a market economy approach. This results in clarity of the results obtained by gravity modeling. This will increase the possibility of a quick, comprehensive use of recreational potential in the regions.

Theoretical implications

The regions will develop strategies for a thorough study of the processes of recreational and recreational use, its dependent and influential factors, gravity modeling, econometric analysis, and recreational activities in the recreational facilities in the region based on prognostication of recreational facilities. At the same time, recreational gravity models will be developed, including short-term (1-year), medium-term (5-year), and long-term (10 to 15-year) models. The econometric and gravitational models used in the current market economy are targeted at a specific recreational and recreational system for selected periods. The gravity models in the recruiting experience have a higher degree of reliability, and over the years, these models can be effectively maintained by changing certain factors. Therefore, achieving a high level of efficiency in achieving the short-term (1-year), medium-term (5-year), and long-term (10 to 15-year) models can lead to strategic planning for three different models. It is necessary to take into account every factor in econometric modeling in the regions in recreational processes.

\footnotetext{
${ }^{8}$ Source: author's work on the basis of the data from the State Statistics Committee of the Republic of Uzbekistan

${ }^{9}$ Source: author's work on the basis of the data from the State Statistics Committee of the Republic of Uzbekistan
} 


\section{Practical implications}

In the context of globalization, the role of recreation in human health improvement and rehabilitation is immensely significant, and human health problems can only be addressed through rock mass, natural orchards, watercourses, rivers, lakes, rivers, reservoirs, canals, sanatoriums, resorts, recreation through activities.

The research has been widely used in today's world-renowned tourism and recreational systems, based on gravitational models of recruiting, and has been based on regional characteristics. Recreation zones are based on conclusions focused on the disputed population and the development of mutual relations between them. The research primarily based on the distance to recreational sites of present-day visitors based on gravity rings. A gravitational model designed for distant visitors at a distance of 100-150 $\mathrm{km}$ operates efficiently, and more remote range of recreational teams have been found to be ineffective.

The econometric model for recreational and recreational activity in Namangan region has been developed based on factors such as the use of recreational resources in the region, recreational competitiveness of the region, recreational infrastructure of the region. At the same time, the activity of "Chartak" sanatorium was investigated for treatment and recreational recreation of recreational object. From the forecast data of the econometric model it can be seen that due to restriction of recreational capacity of the recreational facility it is impossible to expand activity, it is necessary to create a cluster of medical equipment to expand activity and increase the capacity of recreational reception. "Recreational sites, districts, complexes, clusters and recreational facilities and bases are provided to enhance the efficiency of recreational activities".[3] The development of recreational facilities depends on their proper location.

\section{REFERENCES}

1. Abdulkhakimov Z.T. (2019) Creation of tourist-recreational zones and clusters in Namangan region. Economical scientific-practical monthly journal "Business-Expert" № 2

2. Abdulhakimov Z.T. (2017) Recreational resources of Namangan region. Monographs.Tashkent. "Economy" publishing house.

3. Abdulxakimov Z.T. (2018) Development of regional economy with mountain recreation in case Uzbekistan // Bulletin of and Practice scientific gournal. № 5, 446-453 p. DOI:10.5281/zenodo. 1246298 , (GIF -0,454)

4. Abdulhakimov Z.T. (2019) Use of recreational facilities, bases and gravity models in the region. Scientific-analytical journal "Science and Practice" REU them. GVPlekhanova. T.11. No. 1 (33)

5. Dwyer L., Forsyth P., Papatheoderoy A. (2011) Economics of Tourism. Goodfellow Publishers limited, Woodeaton, Oxford.

6. Limonov L.E. (2015) Regional economy and spatial development. $-\mathrm{M}$ : Y Yurait

7. Morozova M.A., Morozova N.S, Karpova G.A., Horeva L.V. (2014) Economy of tourism. Textbook.

8. Navruz-zoda N., Ibragimov N., Navruz-zoda Z.B., Navruzzoda Sh.B.(2017) Competitiveness of tourist zones. Monographs. Bukhara

9. Oborin M.S., Plotnikov A.V, Vladimirsky E.V., Kayachev A.P. (2014) Analysis of the structure of the composition of the resort and recreational system based on system research methods. ASTU bulletin. Economy. N 3.

10. Reilly W.J.(1931) The law of retail gravitation. - New York.

11. 11.Ryabtsev S.M, Malashenkova M.V. (2007) Improving sanatorium-resort treatment in the city of Sochi using various types of active recreation // Fundamental research. №6, Sochi.

12. Sarancha, M.A. (2009) To isotropic models of tourist and recreational migrations. Biology. Earth sciences. No. 1.
13. Soliev A., Ahmedov E., Mahamadalieva R.Y., Nazarov M.I., Tojieva Z.N., Boltaev M.J., Atajanova U.A. (2003) Regional Economics. Educational manual. Tashkent - 2003

14. 14.Usmanova Z.I.(2018) Peculiarities and trends of tourist and recreational services development in Uzbekistan. Samarkand.

15. 15. Zanadvorov V.S., Zanadvorova A.V.(2003) Economy of the city. Introductory course: textbook. -M .: Academic Book ICC

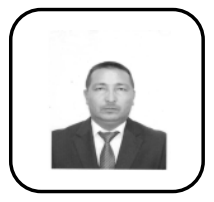

\section{AUTHORS PROFILE}

Zuhrali Abdulkhakimov Tursunalievich was born in 1975. He started his career as a senior laboratory assistant in the Department of General Biology of Namangan State University. In 1999 he was promoted as a teacher to the Department of Economics. In 2005 he started working in the Department of Economics of Namangan Engineering-Economic Institute as a teaching assistant, and in 2008 as a senior lecturer. He was transferred after to the Department of Organization and Economics of Industrial Production and is working there up to date as a senior teacher while doing his Ph.D. research in Samarkand Institute of Economics and Service. He has published 18 articles in local periodicals, and 1 article in international journal, which is cited as Abdulkhakimov Z.T. "Development of regional economy with mountain recreation: in case of Uzbekistan" //Bulletin of Science and Practice, 2018, 4(5), pp. 446-453. DOI:10.5281/zenodo. 1246298

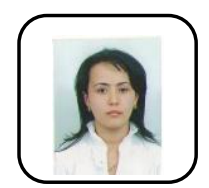

Madina Ibragimova Ismailovna was born in 1984 In 2007 she graduated from Samarkand Institute of Economics and Service and from 2007 to 2009 studied Msc in Economics there. After that, she worked as a specialist in the Department of Training research and pedagogy staff of the institute for 2 years. In 2012 she started her Ph.D.course and since has been working as a teaching assistant in the institute. She has published 11 articles in local scientific journals and1 in the international journal, which is cited as Ibragimova M. "Opportunities and prospects of international experience in the organization of educational tourism"//American Journal of Economics and Business Management, June 2 2019, vol.2, DOI:10.31150/ajebm.Vol2.Iss2.65 